University of Nebraska - Lincoln

DigitalCommons@University of Nebraska - Lincoln

Nebraska Cooperative Fish \& Wildlife Research Nebraska Cooperative Fish \& Wildlife Research Unit -- Staff Publications

2001

\title{
A caloric-based evaluation of diet indices for largemouth bass
}

\author{
Kevin Lee Pope \\ Texas Tech University, kpope2@unl.edu \\ Michael Lee Brown \\ South Dakota State University \\ Walter Gilbert Duffy \\ Humboldt State University \\ Paul Herbert Michaletz \\ Missouri Department of Conservation
}

Follow this and additional works at: https://digitalcommons.unl.edu/ncfwrustaff

Part of the Other Environmental Sciences Commons

Pope, Kevin Lee; Brown, Michael Lee; Duffy, Walter Gilbert; and Michaletz, Paul Herbert, "A caloric-based evaluation of diet indices for largemouth bass" (2001). Nebraska Cooperative Fish \& Wildlife Research Unit -- Staff Publications. 69.

https://digitalcommons.unl.edu/ncfwrustaff/69

This Article is brought to you for free and open access by the Nebraska Cooperative Fish \& Wildlife Research Unit at DigitalCommons@University of Nebraska - Lincoln. It has been accepted for inclusion in Nebraska Cooperative Fish \& Wildlife Research Unit -- Staff Publications by an authorized administrator of DigitalCommons@University of Nebraska - Lincoln. 


\title{
A caloric-based evaluation of diet indices for largemouth bass
}

\author{
Kevin Lee Popea, Michael Lee Brownb, Walter Gilbert Duffy`\& Paul Herbert Michaletzd \\ DDepartment of Range, Wildlife, and Fisheries Management, Texas Tech University, Lubbock, TX 79409, U.S.A. \\ (e-mail: kevinpope@ttuedu) \\ DDpartment of Wildlife and Fisheries Sciences, South Dakota State University, Brookings, SD 57007, U.S.A. \\ (e-mail: michael_brown@sdstateedu) \\ California Cooperative Fishery Research Unit, Humboldt State University, A rcata, CA 95521, U.S.A. \\ (e-mail: wgd700l @axe.humboldt.edu) \\ dMissouri Department of Conservation, 1110 South College Avenue, Columbia, MO 65201, U.S.A. \\ (e-mail: michap@mail.conservation.state.mo.us)
}

Received 2 August $2000 \quad$ Accepted 26 November 2000

Key words: relative importance index, prey importance index, stomach fullness, Micropterus salmoides

\section{Synopsis}

Selection of methods for quantitative description and assessment of food habits is a concern for trophicinvestigations. We used diet data for largemouth bass Micropterus salmoides, to compare a caloric-based approach with eight diet indices: percent frequency of occurrence, percent total number, percent total weight, mean relative number, mean relative volume, relative importance index, prey-importance index, and mean stomach fullness. Mean caloric contribution of stomach contents for each prey taxon was used as a standard to compare diet indices. Temporal differences in composition and caloric contents of largemouth bass stomach contents were apparent. Most diet indices provided similar assessments when diets were dominated by a single prey type (i.e., gizzard shad during June-October). However, diet indices evaluated provided dissimilar assessments of stomach contents when a variety of prey with differing caloric densities were consumed (e.g., April). Mean stomach fullness and percent by volume were significantly $(\mathrm{p}<0.002)$ correlated $(\mathrm{r}=0.94-1.00)$ with mean caloric contribution of largemouth bass stomach contents during all months. Unlike percent by weight, mean stomach fullness accounted for differences in fish size and stomach capacity. Thus, mean stomach fullness by prey type appears to be the most appropriate index when objectives include simplified caloric-based assessments of fish diets.

\section{Introduction}

Biologists have long struggled to determine the appropriate method for quantitative description and assessment of food habits. Frequency of occurrence, percent composition by number and percent composition by weight are three approaches that are often used to describe fish diets (Bowen 1996). Each approach provides distinctly different information and contains biases that may limit the usefulness of any single method (Windell 1971). For example, percent composition by number emphasizes the value of small foods (such as zooplankton) that are consumed in large numbers while de-emphasizing large food items consumed in low numbers. Conversely, percent composition by weight emphasizes the value of large items eaten in small numbers and de-emphasizes small items eaten in large numbers. All three indices provide single values without any measure of variance.

Although providing important summaries, these approaches do not allow statistical comparisons among samples. However, percent composition by number and 
weight (volume) can be calculated for individual fish and then averaged to obtain a mean (referred to in this paper as mean relative number and mean relative volume) and variance for the sample (Wallace 1981). Furthermore, Wallace (1981) concluded that mean relative volume (weight) appeared to be the most appropriate diet measure because (1) volume (weight) of prey likely has some relationship to the caloric value of food and (2) unlike percent composition by volume, mean relative volume does not overemphasize stomach contents of a few individuals at the expense of the overall population diet.

Windell (1971) recommended the use of combined indices over single measures (e.g., frequency of occurrence, percent composition by number, and percent composition by weight). Consequently, Pinkas et al. (1971) proposed the index of relative importance (IRI), which multiplied frequency of occurrence by the sum of percent composition by number and percent composition by volume. George \& Hadley (1979) modified the IRI with the development of the relative importance (RI) index, which is a linear combination of the three single measures. Since its inception, the RI index has been widely used (e.g., Hodgson \& Kitchen 1987, Jackson et al. 1992, Bryan et al. 1995). However, use of RI has not been without controversy. Hyslop (1980) stated that it is unlikely that the RI index is more accurate than a single index because RI is confounded by two sources of error and variation [i.e., error associated with percentages (number and weight) and error associated with frequency of occurrence are different]. Also, arithmetic manipulation of percentages, which are dimensionless ratios, produces numbers of no interpretable meaning (Bowen 1996). Finally, the RI index produces a single value with no variation for each prey taxon consumed by a population; thus, no straightforward statistical comparisons of RI values can be made among populations, stocks, life-history periods, etc.

Alternatively, Probst et al. (1984) took a bioenergetic approach to diet assessment in the development of the prey-importance (PI) index. The PI index is the average proportion of total calories contributed by each prey type. Thus, a mean and variance can be calculated for the PI index. The PI index does not account for seasonal differences in total caloric intake; however, seasonal comparisons of PI values can be made.

In addition to identification of stomach contents, biologists have also been interested in quantifying stomach fullness. Windell (1971) utilized an index of fullness by dividing stomach contents (wet weight) by fish body weight, and then multiplying by 10000 . Biologists have also examined stomach fullness by relating maximum stomach capacity to volume or weight of stomach contents. Several methods of determining stomach capacity have been used. Magnuson (1969) fed starved fish items of known volume until satiated. Kimball \& Helm (1971) experimentally determined stomach capacity for different length fish by measuring the amount of water that could be injected into an empty stomach prior to bursting. Hellawell $(1971,1972)$ and Knight \& Margraf (1982) derived exponential equations that related maximum volume of ingested prey to fish total length. Using these equations, they were able to develop a stomach fullness index by examining the ratio of observed prey volume to estimated maximum stomach capacity for any given length of fish.

Growth of fishes is an important indicator of environmental conditions. Bioenergetic models provide a functional framework for relating growth rates and feeding rates of fish to environmental conditions and provide insight into causal relationships among these variables (Allen \& Wootton 1982). Like all animals, fish convert organic matter and energy that they ingest into living biomass (Bowen et al. 1995, Bowen 1996). Standard metabolism, specific dynamic action, and non-resting activity energy needs must be met first, and any remaining energy is physiologically available for tissue elaboration (Brett \& Groves 1979). Thus, growth of fishes is variable because it is the last need met in the energy budget.

Common applications of bioenergetic models have been estimation of growth or production (Paloheimo \& Dickie 1966, Kerr 1971, Healey 1972, Ware 1975) and prediction of food consumption rates (Kitchen \& Breck 1980, Stewart et al. 1981, 1983, Rice \& Cochran 1984). Most bioenergetic models use energetic units of measurement because many dissimilar materials (protein, lipids, carbohydrates) and processes (ingestion, assimilation, growth, catabolism, etc.) can be described in terms of units of energy required or contained (Warren \& Davis 1967). Hyslop (1980) stated that energetic studies should quantify the contribution of dietary items by caloric content. This type of assessment is tedious and costly to perform on a routine basis. Thus, we investigated eight diet indices using a caloric-based assessment. Our objective was to determine which, if any, of the eight diet indices provide alternatives to caloric-based assessments that are simpler to measure and less time consuming (i.e., exhibit functional utility on an energetic basis). 
Table 1. Caloric values (cal $\mathrm{g}$ ' wet weight) used for prey items of largemouth bass (200 to $299 \mathrm{~mm}$ total length) in Pomme de Terre and Stockton reservoirs, Missouri, during 1991

\begin{tabular}{|c|c|c|}
\hline Prey group & Caloric density (cal g-' ) & Reference \\
\hline \multicolumn{3}{|l|}{ Fish } \\
\hline brook silverside & 1050 & \\
\hline Centrarchidae & 1160 & Miranda \& Muncy (1989) \\
\hline Cyprinidae & 1050 & Bryan et al. (1996) \\
\hline gizzard shad & 1220 & Miranda \& Muncy (1989) \\
\hline other fish & 1100 & 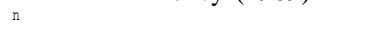 \\
\hline unidentified fish & 1100 & $\mathrm{n}$ \\
\hline \multicolumn{3}{|l|}{ Insects } \\
\hline Coleoptera & 1020 & Cummins \& Wuycheck (1971`) \\
\hline Diptera & 600 & Cummins \& Wuycheck (1971) \\
\hline Ephemeroptera & 1125 & Cummins \& Wuycheck (1971') \\
\hline Hemiptera & 1100 & d \\
\hline Odonata & 1050 & Cummins \& Wuycheck (1971`) \\
\hline other insects & 1050 & \\
\hline Crayfish & 750 & Kelso (1973`) \\
\hline Zooplankton & 475 & Cummins \& Wuycheck (1971) \\
\hline Other invertebrates & 700 & Cummins \& Wuycheck (1971f) \\
\hline
\end{tabular}

aEstimated by authors to be similar to Cyprinidae.

bEstimated by authors to be within caloric density range (i.e., 1050-1220) of other fishes in this assessment.

'Estimated from dry weight caloric density.

dEstimated by authors to be within caloric density range (i.e.,1050-1125) of odonata and ephemeroptera in this assessment.

eEstimated by authors to be within caloric density range (i.e., 600-1125) of other insects in this assessment.

Mean of Annelida and Hirudinea.

\section{Methods}

Largemouth bass, Micropterus salmoides (200$299 \mathrm{~mm}$ total length), from the Lindley Creek Arm of Pomme de Terre Lake and the Sac River Arm of Stockton Lake, both in southwestern Missouri, were collected monthly during April through October 1991 using nighttime electrofishing. Captured largemouth bass were measured (nearest $1 \mathrm{~mm}$ total length), and their stomach contents removed with clear plexiglass tubes. Van Den Avyle \& Roussel (1980) reported that this method removed $100 \%$ of stomach contents from largemouth bass, while Cailteux et al. (1990) reported a recovery rate of $>80 \%$. To improve removal efficiency, we used long forceps and a water squirt bottle to aid in the removal of food contents. We also used a small flashlight with a concentrated beam of light to examine the interior of the stomach while the tube was inserted into the digestive tract to ensure that all food items had been removed. Stomach contents were immediately preserved in $10 \%$ formalin. In the laboratory, all organisms in each stomach sample were identified and counted. Prey organisms were blotted dry and grouped by taxa, and their volume was estimated by water displacement (nearest $1 \mathrm{ml}$ ). When sample volumes of prey taxa were too small to be measured, they were visually estimated as a percentage of the total sample volume. For a more detailed description of the study sites and methods used to collect these data, see Michaletz (1997).

Use of these largemouth bass diet data allowed calculation of frequency of occurrence, percent by number, and percent by volume of prey items. Calculation of RI values required converting percent by volume to percent by weight. Most aquatic organisms have a specific density of 1.02 to $1.05 \mathrm{~g} \mathrm{ml}$-' (Lampert \& Sommer 1997). In addition, we determined the specific density of gizzard shad to be $0.999 \mathrm{~g} \mathrm{ml}$ - ' (unpublished data). Furthermore, Swedberg \& Walburg (1970) derived volume estimates of stomach contents by utilizing a weight : volume ratio of $1: 1$. Therefore, we assumed a specific density of one (i.e., $1 \mathrm{ml}$ displacement $=1 \mathrm{~g}$ 
Table 2. Equations for calculating diet indices

\begin{tabular}{|c|c|}
\hline Diet index & Equations' \\
\hline Mean caloric contribution & $\mathrm{MCal} ;=\underset{\mathrm{p}}{1} \underset{\mathrm{i}=\sim}{\mathrm{p}} \underset{\mathrm{W}}{\sim} ; \mathrm{X} ;$ \\
\hline Frequency of occurrence & $\mathrm{FOC} ;-\mathrm{P}$ \\
\hline Percent by number & $\% \mathrm{TN} ;-\underset{-\mathrm{e} ;}{\sim}$ \\
\hline Percent by weight & $\begin{aligned} \% \mathrm{TW} ;= & \mathbb{Q} \\
& \sim \mathrm{W} .\end{aligned}$ \\
\hline Mean relative number & 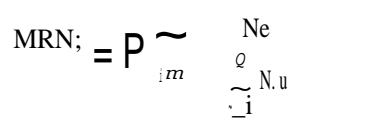 \\
\hline Mean relative volume & 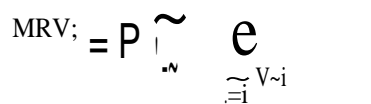 \\
\hline Relative importance index & $\begin{array}{l}\mathrm{RI} ;-\frac{100 \mathrm{AL}}{\mathrm{AI} ;} \\
\mathrm{AI} ;=\mathrm{FOC} ;+\% \mathrm{TN} ;+\% \mathrm{TW} ;\end{array}$ \\
\hline Prey importance index & $\mathrm{PI}=\mathrm{P}-\frac{\mathrm{W} \mathrm{X}^{\prime}}{\mathrm{Q}}$ \\
\hline Mean stomach fullness & $\mathrm{MSF}^{\prime}=\mathrm{P} \sim \sim \mathrm{CJ}$ \\
\hline \multicolumn{2}{|c|}{$\begin{array}{l}\text { ai }=\text { food type. } Q=\text { number of food categories. } \mathrm{j}=\text { fish. } \mathrm{P}= \\
\text { number of fish with food in their stomach. } \mathrm{J} ;=\text { number of fish } \\
\text { containing one or more of prey i. } \mathrm{N} ;=\text { number in food category } \\
\text { i. } \mathrm{W} ;=\text { weight }(\mathrm{g}) \text { of food category } \mathrm{i} . \mathrm{V} ;=\text { volume }(\mathrm{ml}) \text { of food } \\
\text { category i. } \mathrm{X} ;=\text { caloric value (cal g ' wet weight) of food category } \\
\text { i. } \mathrm{C} ;=\text { stomach capacity of fish } \mathrm{j} \text {. }\end{array}$} \\
\hline
\end{tabular}

wet weight) for all prey items; thus, percent by volume was easily converted to percent by weight for calculating $\mathrm{RI}$ values.

We obtained caloric density (cal g ' wet weight) values for most prey items from published literature and estimated the remaining values (Table 1). We multiplied caloric density by total estimated wet weight of each prey item for each largemouth bass to obtain the caloric contribution of each prey type consumed by that fish. A mean caloric contribution for each prey taxon was calculated (Table 2; zero was used for prey taxa not eaten by an individual largemouth bass) for each month and reservoir and was used as our standard to evaluate the other eight diet indices.
Frequency of occurrence, percent by number, and percent by volume of each prey category were calculated (Table 2) for the entire population diet. Relative number $(\%)$ and relative volume $(\%)$ of each prey item were calculated for each individual fish. Then mean relative number and mean relative volume (Table 2; zero was used for prey taxa not consumed by an individual fish) were derived for prey groups by each month and reservoir. Values for the RI index were calculated to obtain average contributions of prey types based on a linear combination of frequency of occurrence, percent by number, and percent by weight. Prey-importance index values were calculated (zero included for prey taxa not consumed by an individual fish) to obtain mean relative 
Table 3. Mean daily water temperature $\left({ }^{\circ} \mathrm{C}\right)$ and sample size $(\mathrm{N})$ and mean caloric contribution of prey items for largemouth bass (200 to $299 \mathrm{~mm}$ total length) from Pomme de Terre and Stockton lakes, Missouri, during 1991

\begin{tabular}{|c|c|c|c|c|c|c|c|c|}
\hline Lake & Category & Apr & May & Jun & Jul & Aug & Sep & Oct \\
\hline \multirow[t]{20}{*}{ Pomme de Terre } & Water temperature & 14.6 & 21.7 & 27.1 & 28.6 & 27.3 & 24.5 & 18.3 \\
\hline & $\mathrm{N}$ & 25 & 23 & 25 & 36 & 39 & 30 & 36 \\
\hline & Fish & & & & & & & \\
\hline & brook silverside & 0 & 27 & 0 & 12 & 35 & 0 & 0 \\
\hline & Centrarchidae & 232 & 1485 & 93 & 1 & 110 & 101 & 796 \\
\hline & Cyprinidae & 0 & 0 & 0 & 0 & 0 & 0 & 0 \\
\hline & gizzard shad & 288 & 42 & 1388 & 1644 & 1289 & 2021 & 2326 \\
\hline & other fish & 286 & 0 & 0 & 0 & 0 & 0 & 0 \\
\hline & Unidentified fish & 1 & 4 & 88 & 3 & 3 & 0 & 0 \\
\hline & Insects & & & & & & & \\
\hline & Coleoptera & 0 & 0 & 0.4 & 3 & 0 & 0 & 0 \\
\hline & Diptera & 22 & 4 & 0.2 & 2 & 0.5 & 0.2 & 1 \\
\hline & Ephemeroptera & 30 & 2 & 1 & 0 & 1 & 0.4 & 0 \\
\hline & Hemiptera & 0 & 0 & 0 & 0 & 0 & 0 & 0 \\
\hline & Odonata & 0 & 0 & 0 & 0 & 6 & 0.7 & 0 \\
\hline & other insects & 0 & 2 & 0 & 0 & 0 & 0 & 0 \\
\hline & Crayfish & 291 & 388 & 0 & 0 & 29 & 50 & 54 \\
\hline & Zooplankton & 0.4 & 0 & 0.2 & 0.1 & 0.1 & 0 & 0 \\
\hline & other invertebrates & 0 & 0 & 1 & 1 & 0.2 & 0 & 0 \\
\hline & Total calories & 1151 & 1956 & 1871 & 1665 & 1474 & 2173 & 3177 \\
\hline \multirow[t]{20}{*}{ Stockton } & Water temperature & 14.7 & 21.0 & 26.5 & 27.7 & 26.7 & 24.3 & 18.3 \\
\hline & $\mathrm{N}$ & 30 & 27 & 20 & 37 & 38 & 39 & 27 \\
\hline & Fish & & & & & & & \\
\hline & brook silverside & 0 & 0 & 0 & 40 & 14 & 135 & 261 \\
\hline & Centrarchidae & 236 & 116 & 99 & 304 & 452 & 217 & 473 \\
\hline & Cyprinidae & 49 & 0 & 0 & 0 & 0 & 0 & 0 \\
\hline & gizzard shad & 191 & 429 & 528 & 1213 & 2219 & 1492 & 1412 \\
\hline & other fish & 301 & 338 & 0 & 67 & 0 & 0 & 139 \\
\hline & Unidentified fish & 6 & 0 & 0 & 0 & 0 & 6 & 16 \\
\hline & Insects & & & & & & & \\
\hline & Coleoptera & 3 & 0 & 2 & 0 & 0 & 0 & 0 \\
\hline & Diptera & 18 & 3 & 0 & 0.2 & 0 & 0.3 & 0.2 \\
\hline & Ephemeroptera & 60 & 57 & 12 & 2 & 0 & 1 & 2 \\
\hline & Hemiptera & 0 & 1 & 0 & 0 & 3 & 0 & 0 \\
\hline & Odonata & 0 & 0 & 21 & 0 & 0 & 0 & 0 \\
\hline & other insects & 4 & 0 & 1 & 12 & 0 & 0 & 0 \\
\hline & Crayfish & 75 & 81 & 105 & 15 & 101 & 8 & 56 \\
\hline & Zooplankton & 0.3 & 2 & 0 & 0 & 0.1 & 0 & 0 \\
\hline & other invertebrates & 2 & 2 & 0.4 & 1 & 0 & 0 & 0 \\
\hline & Total calories & 944 & 1029 & 768 & 1653 & 2788 & 1858 & 2357 \\
\hline
\end{tabular}

(\%) caloric composition for each prey group by month and reservoir.

Maximum calories ingested are primarily limited by proximate composition of prey, digestion rates, and stomach volume. We calculated mean stomach fullness for each prey taxon (i.e., the percentage of maximum stomach capacity that each prey taxon fulfilled) by developing a stomach capacity-length equation using methods similar to Knight \& Margraf (1982). To develop the equation, we first combined all data on largemouth bass $(\mathrm{N}=2898)$ collected from Pomme de Terre and Stockton reservoirs during 1987-1991 (Michaletz 1997). Data then were divided into $2 \mathrm{~cm}$ length groups; length groups with a sample size less than 10 were eliminated (remaining $N=2864$ ). Maximum total volume of prey observed in each $2 \mathrm{~cm}$ length group was plotted as a function of the midpoint of each length group and used to derive an exponential regression equation that related stomach capacity $(\mathrm{ml})$ to total length $(\mathrm{mm})$. 


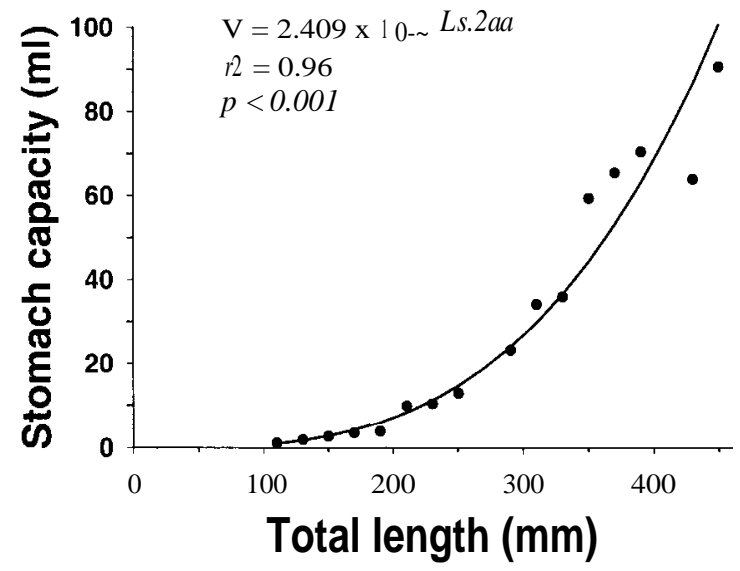

Figure 1. Relationship between maximum stomach capacity (V) and total length ( $\mathrm{L}$ ) of largemouth bass in Pomme de Terre and Stockton reservoirs, Missouri. A point represents the maximum total volume of prey observed in an individual stomach plotted as the midpoint for each $2 \mathrm{~cm}$ length group.

Diet indices were evaluated by correlating (Pearson product-moment correlation) calculated index values for prey taxa within each month and reservoir with mean caloric contribution for prey taxa. Statistical significance was set at $\mathrm{a}=0.05$, but was adjusted using the sequential Bonferroni technique (Miller 1981, Rice 1989) within each reservoir to control the probability of incorrectly rejecting one or more true null hypotheses. This adjustment was needed because we conducted multiple simultaneous correlations within each reservoir.

\section{Results}

\section{Caloric content of diet}

Temporal differences in caloric contribution of largemouth bass stomach contents were observed in Pomme de Terre and Stockton reservoirs (Table 3). In Pomme de Terre Lake, largemouth bass obtained most of their energy from fishes and crayfish Procambarus spp. during April, from centrarchids during May, and from gizzard shad, Dorosoma cepedianum, during June through October. In Stockton Lake, largemouth bass obtained most of their energy from fishes during April and May and from gizzard shad during June through October. Total caloric contribution of largemouth bass stomach contents tended to increase from April through October in both populations.

\section{Dynamics of diet indices}

An exponential regression equation significantly $(p<0.001)$ related maximum largemouth bass stomach capacity with total length (Figure 1); thus, this equation was used to calculate mean stomach fullness. Temporal differences in values of diet indices for prey taxa found in largemouth bass were observed in both reservoirs (Figures 2,3). All diet indices provided large values for gizzard shad during June through October in both reservoirs. However, values of diet indices differed during April in both reservoirs. During this period, prey volume was composed mainly of Diptera, Ephemeroptera, crayfish and gizzard shad. Crayfish and Diptera provided the largest PI values for largemouth bass diets in Pomme de Terre Lake and Ephemeroptera had the largest PI value for largemouth bass diets in Stockton Lake.

The largest RI values for largemouth bass prey were for Diptera during April in both reservoirs. During May, centrarchids had the largest RI value for largemouth bass diets in Pomme de Terre Lake; Ephemeroptera provided the largest RI value for largemouth bass diets in Stockton Lake. During June through October, the largest values for each of the three components of the RI index (i.e., percent frequency of occurrence, percent total numbers and percent total weight) were for gizzard shad. However, no single prey item accounted for the largest value of all three components of the RI index during April through May in either reservoir. For example, during April, crayfish dominated total weight of diet for largemouth bass in Pomme de Terre Lake, while crayfish only accounted for $2 \%$ of total numbers of largemouth bass prey and only occurred in $32 \%$ of largemouth bass containing food in their stomachs. In that sample, Diptera were found in $88 \%$ of largemouth bass stomachs containing food and accounted for $90 \%$ of total numbers of prey, but only made up $3 \%$ of total weight of prey items.

\section{Assessment of indices}

During June through September in Pomme de Terre Lake and June, July, September, and October in Stockton Lake, all diet indices were significantly $(p \sim 0.0004)$ correlated with mean caloric contribution of largemouth bass stomach contents (Table 4). During April in Pomme de Terre Lake and April through May in Stockton Lake, only mean stomach fullness $(p=0.0006)$ and percent total weight $(p=0.0003)$ 

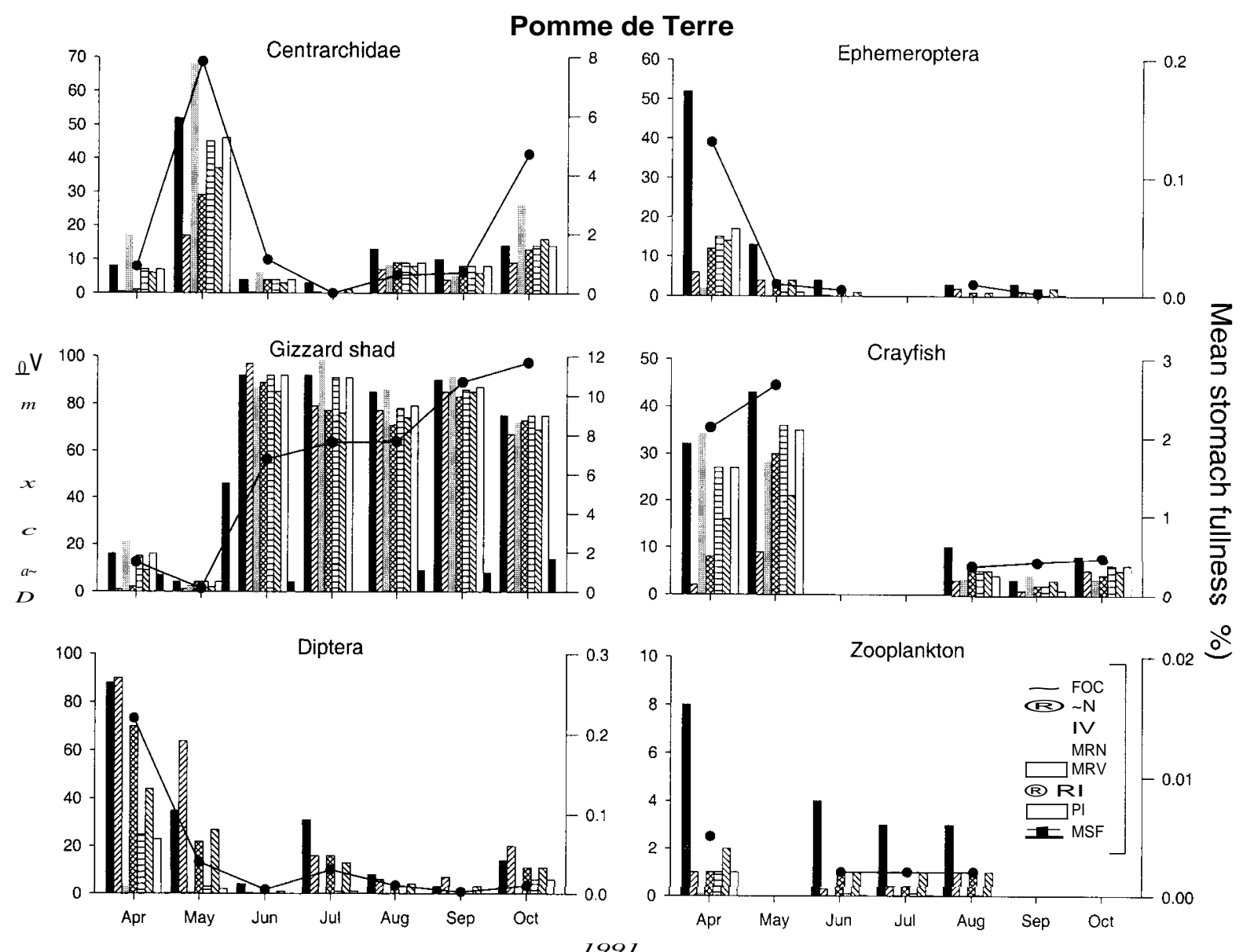

Figure 2. Percent frequency of occurrence (FOC), percent total numbers $(\% \mathbf{N})$, percent total volume $(\% \mathrm{~V})$, mean relative number (MRN), mean relative volume (MRV), relative importance (RI) values, prey importance (PI) values, and mean stomach fullness (MSF) by selected prey type for largemouth bass (200 to $299 \mathrm{~mm}$ total length) diets from Pomme de Terre Lake, Missouri, during 1991 (note: scales of y-axes vary).

were significantly correlated with mean caloric contribution of each prey taxon consumed. Thus, most diet indices provided similar assessments when diets were dominated by a single prey type (i.e., gizzard shad during June-October). However, diet indices provided dissimilar assessments of stomach contents when a variety of prey with differing caloric densities were consumed (e.g., April).

\section{Discussion}

Within each reservoir, largemouth bass diets were composed of primarily gizzard shad during June through
October. During April, prey taxa contributing to largemouth bass diets varied considerably as did the caloric densities of these prey. This diverse diet proved to be the most useful for illustrating energetic differences in the various diet indices.

All diet indices provided similar assessments of largemouth bass diet when caloric density of prey taxa varied little such as occurred during months when diets were dominated by fishes (i.e., June-October). Fish caloric densities ranged from 1050 to $1220 \mathrm{cal} \mathrm{g}$ ' wet weight. Largest disparities occurred when multiple prey taxa with different caloric densities were consumed, such as occurred in April when prey caloric densities ranged from 750 (crayfish) to $1220 \mathrm{cal} \mathrm{g-'}$ (gizzard shad). 


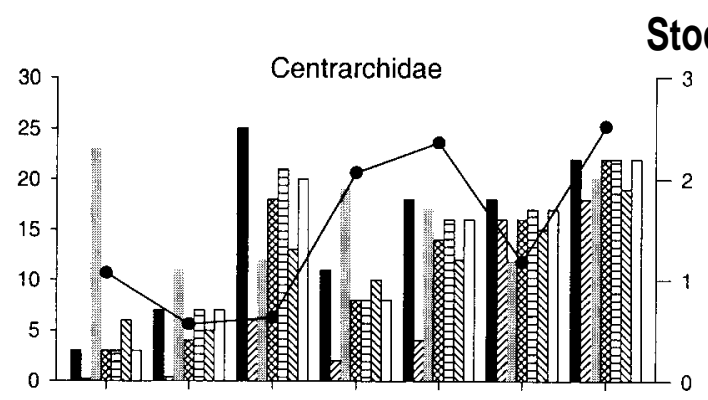

\section{Stockton}
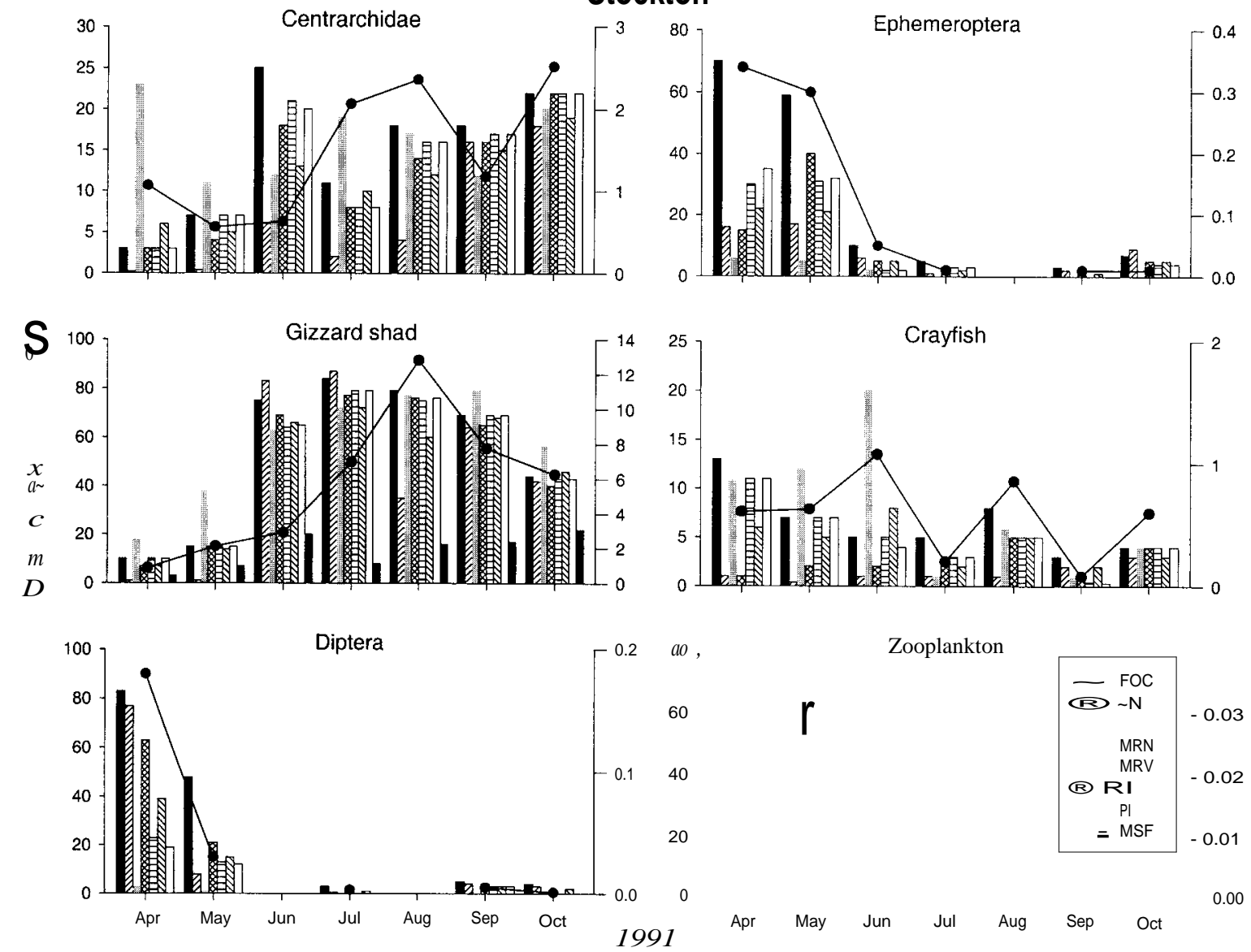

Figure 3. Percent frequency of occurrence (FOC), percent total numbers $(\% \mathrm{~N})$, percent total volume (\% V), mean relative number (MRN), mean relative volume (MRV), relative importance (RI) values, prey importance (PI) values, and mean stomach fullness (MSF) by selected prey type for largemouth bass (200 to $299 \mathrm{~mm}$ total length) diets from Stockton Lake, Missouri, during 1991 (note: scales of y-axes vary).

If total calories ingested does not change over time, then the PI index would provide an assessment equivalent to mean caloric contribution of stomach contents (i.e., the standard we used). However, temporal differences in total caloric contribution of largemouth bass stomach contents were observed in Pomme de Terre and Stockton reservoirs (Table 3). Such seasonal changes in consumption and growth patterns are common and have been observed for largemouth bass in Tennessee (Adams et al. 1982b), Minnesota (Cochran \& Adelman 1982) and West Virginia (Perry et al. 1995). Seasonal changes in total caloric intake by largemouth bass were documented in Watts Bar Reservoir, Tennessee (Adams et al. 1982a). Similarly, Seaburg $\&$ Moyle (1964) found seasonal differences in food consumption for bluegill Lepomis macrochirus, pumpkinseed L. gibbosus, and black crappie Pomoxis nigromaculatus in two Minnesota lakes. Kelso (1973) found seasonal differences in total calories consumed by walleye Stizostedion vitreum. Furthermore, Bennett \& Gibbons (1972) found seasonal changes in subjective estimates of stomach fullness for largemouth bass in a South Carolina reservoir. On a narrower temporal scale, daily differences in food consumption have been documented for age-0 largemouth bass in laboratory tanks (Smagula \& Adelman 1982).

In addition to temporal changes in total consumption, seasonal changes occur in caloric density of prey (Kelso 1973, Strange \& Pelton 1987, Miranda \& Muncy 1989, Bryan et al. 1996) and digestion rates 
Table 4. Pearson correlation coefficients of mean caloric contribution (MCaI) with mean relative number (MRN), mean relative volume (MRV), relative importance (RI) values, percent frequency of occurrence (FOC), percent by number $(\% \mathrm{~N})$, percent by volume $(\% \mathrm{~V})$, prey importance $(\mathrm{PI})$ values, and mean stomach fullness (MSF) of prey items for largemouth bass (200 to $299 \mathrm{~mm}$ total length) from Pomme de Terre and Stockton lakes, Missouri, during 1991. Significant correlation coefficients, as determined by the sequential Bonferroni technique, are indicated with asterisks

\begin{tabular}{llccccccc} 
Lake & Comparison & Apr & May & Jun & Jul & Aug & Sep & Oct \\
\hline Pomme de Terre & MCaI and FOC & -0.3249 & 0.7533 & $0.9945^{*}$ & $0.9449^{*}$ & $0.9960^{*}$ & $0.9992^{*}$ & 0.9515 \\
& MCaI and \% N & -0.3619 & 0.0511 & $0.9966^{*}$ & $0.9796^{*}$ & $0.9975^{*}$ & $0.9968^{*}$ & 0.8975 \\
& MCaI and \%V & $0.9523^{*}$ & $0.9902^{*}$ & $0.9999^{*}$ & $1.0000^{*}$ & $0.9999^{*}$ & $0.9999^{*}$ & $0.9998^{*}$ \\
& MCaI and MRN & -0.3294 & 0.6797 & $0.9994^{*}$ & $0.9811^{*}$ & $0.9981^{*}$ & $0.9988^{*}$ & 0.9597 \\
& MCaI and MRV & 0.2855 & $0.8935^{*}$ & $0.9996^{*}$ & $0.9994^{*}$ & $0.9990^{*}$ & $0.9984^{*}$ & 0.9747 \\
& MCaI and RI & -0.1545 & 0.7739 & $0.992^{*}$ & $0.9857^{*}$ & $0.9989^{*}$ & $0.9997^{*}$ & 0.9718 \\
Stockton & MCaI and PI & 0.3056 & $0.9063^{*}$ & $0.9996^{*}$ & $0.9994^{*}$ & $0.9991^{*}$ & $0.9983^{*}$ & 0.9748 \\
& MCaI and MSF & $0.9354^{*}$ & $0.9969^{*}$ & $0.9950^{*}$ & $0.9999^{*}$ & $0.9997^{*}$ & $0.9999^{*}$ & $0.9981^{*}$ \\
& MCal and FOC & -0.1714 & -0.2190 & $0.9691^{*}$ & $0.9772^{*}$ & $0.9995^{*}$ & $0.9959^{*}$ & $0.9654^{*}$ \\
& MCaI and \%N & -0.2043 & -0.3185 & $0.9734^{*}$ & $0.9720^{*}$ & 0.3210 & $0.9949^{*}$ & $0.9702^{*}$ \\
& MCaI and \%V & $0.9924^{*}$ & $0.9940^{*}$ & $0.9921^{*}$ & $0.9999^{*}$ & $0.9996^{*}$ & $0.9999^{*}$ & $0.9994^{*}$ \\
& MCaI and MRN & -0.1462 & -0.0304 & $0.9731^{*}$ & $0.9835^{*}$ & $0.9998^{*}$ & $0.9960^{*}$ & $0.9590^{*}$ \\
& MCaI and MRV & 0.0064 & 0.1687 & $0.9768^{*}$ & $0.9857^{*}$ & $0.9995^{*}$ & $0.9956^{*}$ & $0.9692^{*}$ \\
& MCaI and RI & 0.0234 & 0.0792 & $0.9932^{*}$ & $0.9885^{*}$ & $0.9546^{*}$ & $0.9981^{*}$ & $0.9889^{*}$ \\
& MCaI and PI & 0.0213 & 0.1681 & $0.9769^{*}$ & $0.9858^{*}$ & $0.9995^{*}$ & $0.9955^{*}$ & $0.9698^{*}$ \\
& MCaI and MSF & $0.9740^{*}$ & $0.9948^{*}$ & $0.9843^{*}$ & $0.9990^{*}$ & $0.9995^{*}$ & $0.9994^{*}$ & $0.9943^{*}$
\end{tabular}

of predators (Markus 1932, Adams \& Breck 1990). To keep our assessment as simple as possible, we did not incorporate seasonal changes in caloric density of prey or digestion rates for our evaluation of these diet indices. Variable rates of digestion have been found to cause errors in determination of dietary importance (Gannon 1976, Berg 1979); however, errors in bulk measurement resulting from variable digestion rates will affect all diet indices similarly. Biologists conducting energetic-based diet assessments should be aware of the potential for seasonal changes in prey-body composition and digestion rates.

Mean stomach fullness and percent total volume were the only diet indices that were significantly correlated with mean caloric contribution of stomach contents during all months (Table 4). These two indices provided better assessments of food habits than other diet indices because there is relatively little variation (i.e., well less than one order of magnitude) in caloric densities of prey items and thus, total caloric intake is primarily dependent on volume consumed. Mean relative volume of stomach contents did not provide a useful assessment of largemouth bass diet because caloric intake and caloric requirements are size specific. For example, consumption of $10 \mathrm{ml}$ of gizzard shad would provide a larger percentage of energy requirements to a $100 \mathrm{~mm}$ largemouth bass compared to a $500 \mathrm{~mm}$ bass.
Mean relative volume of prey did not account for size differences in the predator even though we only looked at a small total length (200-299 $\mathrm{mm}$ ) range of largemouth bass. In contrast, mean stomach fullness by prey type was based on length and therefore, accounted for differences in predator size and, as recommended by Hyslop (1980), stomach capacity.

Percent total volume (weight) also did not account for differences in predator size. In fact, percent total volume does not provide an individual assessment of diet, but only provides one population value (i.e., percent of total volume of prey i consumed by all fish examined). In addition, percent total volume is likely influenced most by larger fish in the sample because their stomachs are physically larger, and thus, are able to contain more and larger prey. However, smaller fish generally consume a larger percentage of their body weight than larger fish (Williams 1959, Wright 1970).

When possible, we recommend that diet assessments be based on caloric values of food. However, we recognized that mean caloric contributions must likely be compiled from a variety of sources [e.g., volume (weight) of diet items, published literature, and calorimetry]. In addition, like all other diet assessment methods, an assessment based on caloric values is dependent upon assumptions. Based on our assessment of these eight diet indices, we believe that mean 
stomach fullness has reasonable utility for energetic diet assessments and is a good substitute for mean caloric contributions. However, mean stomach fullness also has limitations. For example, mean stomach fullness-length relationships are currently undefined for most species and thus, would likely have to be developed by researchers conducting diet assessments.

Current bioenergetics models are based on biomass and caloric densities of both predator and prey (Adams $\&$ Breck 1990). Therefore, an assessment of mean stomach fullness based on weight rather than length would be more appropriate. However, length is the commonly used correlate of fish weight (Anderson \& Neumann 1996) and it is easier to obtain accurate length measurements than weight measurements in the field. We believe that an assessment of mean stomach fullness based on fish weight will provide similar results to an assessment based on fish length. Thus, we believe that species-specific standard fullness equations need to be developed based on fish length.

Finally, values from individual prey groups cannot be summed to obtain combined values (e.g., grouping fish into one category and insects in another) for some diet indices such as the RI index because frequency of occurrence has to be recalculated. In contrast, mean caloric and mean stomach fullness values can be summed for combined assessments. Thus, diet assessments using mean stomach fullness values of individual prey taxa that are not combined will provide investigators with more information. Investigators can easily sum groups for a combined assessment, but they cannot separate combined values into their respective parts.

\section{Acknowledgements}

Timothy Bonner, Charles Dabbert, Dennis DeVries, Reynaldo Patiiio, Brian Van Zee, David Willis and Russell Wright provided critical comments on earlier drafts of this manuscript. This is contribution T 9-833 of the College of Agricultural Sciences and Natural Resources, Texas Tech University, Lubbock.

\section{References cited}

Adams, S. M. \& J. E. Breck. 1990. Bioenergetics. pp. 38915. In: C. B. Schreck \& P. B. Moyle (ed.), Methods for Fish Biology, American Fisheries Society, Bethesda.

Adams, S. M., R. B. McLean \& M.M. Huffman. 1982a.Structuring of a predator population through temperature-mediated effects on prey availability. Can. J. Fish. Aquat. Sci. 39: 11751184 .

Adams, S. M., R. B. McLean \& L A Parrotta. 1982b.Energy partitioning in largemouth bass under conditions of seasonally fluctuating prey availability. Trans. Amer. Fish. Soc. 111: 549558.

Allen, J. R. M. \& R.J. Wootton. 1982. The effect of ration and temperature on the growth of the three-spined stickleback, Gasterosteus aculeatus L. J. Fish Biol. 20: 40922.

Anderson, R. O. \& R. M. Neumann. 1996. Length, weight, and associated structural indices. pp. $447 \quad$ 82. In: B. R. Murphy \& D. W. Willis (ed.), Fisheries Techniques, 2nd edition, American Fisheries Society, Bethesda.

Bennett, D. H. \& L W. Gibbons. 1972. Food of largemouth bass (Micropterus salmoides) from a South Carolina reservoir receiving heated effluent. Trans. Amer. Fish. Soc. 101: 650654.

Berg, J. 1979. Discussion of methods of investigating the food of fishes, with reference to a preliminary study of the prey of Gobiusculus flavescens (Gobiidae). Marine Biology 50: 263273.

Bowen, S. H. 1996. Quantitative description of the diet. pp. 513532. In: B. R. Murphy \& D. W. Willis (ed.), Fisheries Techniques, 2nd edition, American Fisheries Society, Bethesda.

Bowen, S. H., E. V Lutz \& $\mathrm{M} \Omega$ Ahlgren 1995 Dietary protein and energy as determinants of food quality: trophic strategies compared. Ecology 76: 899-907.

Brett, J. R. \& I D.D.Groves. 1979. Physiological energetics. pp. 279-352. In: W. S. Hoar, D. 7. Randall \& J. R. Brett (ed.), Fish Physiology, volume 8, Academic Press, New York.

Bryan, S. D., T. D. Hill, S. T. Lynott \& W. G. Duffy 1995. The influence of changing water levels and temperatures on the food habits of walleye in Lake Oahe, South Dakota. J. Freshwater Ecol. 10: 1-10.

Bryan, S. D., C. A. Soupir, W. G. Duffy \& C.E. Ereiburger 1996 Caloric densities of three predatory fishes and their prey in Lake Oahe, South Dakota. J. Freshwater Ecol. 11: 153-161.

Cailteux, R. L., W. F. Porak \& S. Crawford. 1990. Reevaluating the use of acrylic tubes for collection of largemouth bass stomach contents. Proc Annu Conf. Southeast. Assoc. Fish and Wildl. Agencies 44: 126-132.

Cochran, P. A. \& L R Adelman. 1982. Seasonal aspects of daily ration and diet of largemouth bass, Micropterus salmoides, with an evaluation of gastric evacuation rates. Env. Biol. Fish. 7: 265-275.

Cummins, K. W. \& L.C. Wuycheck. 1971. Caloric equivalents for investigations in ecological energetics. Mitt. int. Ver. Limnol. 18: 1-158.

Gannon, J. E. 1976. The effects of differential digestion rates of zooplankton by alewife, Alosapseudoharengus, on determinations of selective feeding. Trans. Amer. Fish. Soc. 105: 89-95.

George, E. L. \& W E Hadley 1979 Fond and habitat partitioning between rock bass (Ambloplites rupestris) and smallmouth bass (Micropterus dolomieui) young of the year. Trans. Amer. Fish. Soc. 108: 253-261.

Healey, M. C. 1972. Bioenergetics of the sand goby (Gobius minutus) population. J. Fish. Res. Board Can. 29: 187-194.

Hellawell, J. M. 1971. The autoecology of chub, Squabs sephalus (L.) of the River Lugg and Afon Llynfi. III. Diet and feeding habits. Freshwater Biology 1: 369-387. 
Hellawell, J. M. 1972. The growth, reproduction and food of the roach, Rutilus rutilus (L.) of the River Lugg, Herefordshire. J. Fish Biol. 4: 469-486.

Hodgson, J. R. \& I E Kitchen 1987 Opportunistic foraging by largemouth bass (Micropterus salmoides). Amer. Mid. Nat. 118: 323-336.

Hyslop, E. J. 1980. Stomach contents analysis-a review of methods and their application. J. Fish Biol. 17: 41129.

Jackson, J. J., D. W. Willis \& D.G. Fielder. 1992. Foed habits of young-of-the-year walleyes in Okobojo Bay of Lake Oahe, South Dakota. J. Freshwater Ecol. 7: 329-341.

Kelso, L R M. 1973. Seasonal energy changes in walleye and their diet in West Blue Lake, Manitoba. Trans. Amer. Fish. Soc. 102: 363-368.

Kerr, S. R. 1971. Prediction of fish growth efficiency in nature. L Eish.Res. Board Can. 28: 809-814.

Kimball, D. C. \& W T_Helm_1971 $\$$ method of estimating fish stomach capacity. Trans. Amer. Fish. Soc. 100: 572-575.

Kitchen, J. F. \& L E. Breck 1980 Bioenergetics model and foraging hypothesis for sea lamprey (Petromyzon marinas). Can. J. Fish. Aquat. Sci. 37: 2159-2168.

Knight, R. L. \& E.J Margraf 1982.Estimating stomach fullness in fishes. North Amer. J. Fish. Manage. 2: 41314.

Lampert, W. \& U. Sommer. 1997. Limnoecology: the ecology of lakes and streams. Oxford University Press, New York. 382 pp.

Magnuson, J. J. 1969. Digestion and food consumption by skipjack tuna (Katsuwonus pelamis). Trans. Amer. Fish. Soc. 98: 379-392.

Markus, H. C. 1932. The extent to which temperature changes influence food consumption in largemouth bass (Huro ftoridana). Trans. Amer. Fish. Soc. 62: 202-210.

Michaletz, P. H. 1997. Influence of abundance and size of age-0 gizzard shad on predator diets, diet overlap, and growth. Trans. Amer. Fish. Soc. 126: 101-111.

Miller, R. G., Jr. 1981. Simultaneous statistical inference, 2nd edition. Springer-Verlag, New York. 299 pp.

Miranda, L. E. \& R.J Muncy 1989 Bioenergetic values of shads and sunfishes as prey for largemouth bass. Proc Anna. Conf. Southeast Assoc. Fish Wildl. Agencies 43: 153-163.

Paloheimo, J. E. \& L M Dickie 1966. Food and growth of fishes. III. Relationships among food, body size, and growth efficiency.J.Fish. Res. Board Can. 23: 1209-1248.

Perry, W. B., W. A. Janowsky \& E.J Margraf 1995 A bioenergetics simulation of the potential effects of angler harvest on growth of largemouth bass in a catch-and-release fishery. North Amer. J. Fish. Manage. 15: 705-712.

Pinkas, L., M. S. Oliphant \& L L K Iverson 1971.Food habits of albacore, bluefin tuna and bonito in California waters. California Fish and Game 152: 1-105.
Probst, W. E., C. F. Rabeni, W. G. Covington \& R E Marteney 1984. Resource use by stream-dwelling rock bass and smallmouth bass. Trans. Amer. Fish. Soc. 113: 283-294.

Rice, W. R. 1989. Analyzing tables of statistical tests. Evolution 43: 223-225.

Rice, J. A. \& D A Cochran 1984. Independent evaluation of a bioenergetics model for largemouth bas. Ecology 65: 732-739.

Seaburg, K. G. \& I B Moyle 1964_Feeding habits, digestive rates, and growth of some Minnesota warmwater fishes. Trans. Amer. Fish. Soc. 93: 269-285.

Smagula, C. M. \& L R Adelman 1982 Day-to-day variation in food consumption by largemouth bass. Trans. Amer. Fish. Soc. 111: 543-548

Stewart, D. J., J. F. Kitchen \& L. B. Crowder. 1981. Forage fishes and their salmonid predators in Lake Michigan. Trans. Amer. Fish. Soc. 110: 751-763.

Stewart, D. J., D. Weininger, D. V Rottiers \& I A. Edsall 1983.An energetics model for lake trout, Salvelinus namaycush: application to the Lake Michigan population. Can. J. Fish. Aquat. Sci. 40: 681-698.

Strange, R. 7. \& L C. Pelton 1987 Nutrient content of clupeid forage fishes. Trans. Amer. Fish. Soc. 116: 60-66.

Swedberg, D. V \& C.H Walburg 1970. Spawning and early life history of the freshwater drum in Lewis and Clark Lake, Missouri River. Trans. Amer. Fish. Soc. 99: 560-570.

Van Den Avyle, M. J. \& L E. Roussel 1980. Evaluation of a simple method for removing food items from live black bass. The Progressive Fish-Culturist 42: 222-223.

Wallace, R. K., 7r. 1981. An assessment of diet-overlap indexes. Trans. Amer. Fish. Soc. 110: 72-76.

Ware, D. M. 1975. Growth, metabolism, and optimal swimming speed of a pelagic fish.J.Fish. Res. Board Can. 32: 33111.

Warren, C. E. \& G.E. Davis. 1967.Laboratory studies on the feeding, bioenergetics, and growth of fish. pp. 175-214. In: S. D. Gerking (ed.), The Biological Basis of Freshwater Fish Production, Blackwell Scientific Publications, Oxford.

Williams, W. E. 1959. Food conversion and growth rates for largemouth bass and smallmouth bass in laboratory aquaria. Trans. Amer. Fish. Soc. 88: 125-127.

Windell, J. T. 1971. Food analysis and rate of digestion. pp. 215-226. In: W. E. Ricker (ed.), Methods for Assessment of Fish Production in Fresh Waters, International Biological Programme Handbook 3, Blackwell, Oxford.

Wright, L. D. 1970. Forage size preference of the largemouth bass. The Progressive Fish-Culturist 32: 39-42. 